\title{
A new genus of proteocephalid tapeworm (Cestoda) from the marbled swamp eel Synbranchus marmoratus Bloch (Synbranchiformes: Synbranchidae) in the River Paraná basin, Argentina
}

\author{
Nathalia J. Arredondo ${ }^{1}$, Philippe Vieira Alves ${ }^{2,3}$ and Alicia A. Gil de Pertierra ${ }^{4}$ \\ ${ }^{1}$ Instituto de Biodiversidad y Biología Experimental y Aplicada (IBBEA, CONICET-UBA), Facultad de Ciencias Exactas y \\ Naturales, Universidad de Buenos Aires, Buenos Aires, Argentina; \\ ${ }^{2}$ Programa de Pós-Graduação em Biologia Animal, Universidade Federal Rural do Rio de Janeiro, Seropédica, Rio de Janeiro, Brazil; \\ ${ }^{3}$ Institute of Parasitology, Biology Centre of the Czech Academy of Sciences, České Budějovice, Czech Republic; \\ ${ }^{4}$ Departamento de Biodiversidad y Biología Experimental, Facultad de Ciencias Exactas y Naturales, Universidad de Buenos Aires, \\ Buenos Aires, Argentina
}

\begin{abstract}
Synbranchiella gen. n. is proposed to accommodate Synbranchiella mabelae sp. n. (Proteocephalidae: Monticelliinae) from the intestine of the marbled swamp eel Synbranchus marmoratus Bloch, in the River Colastiné, a tributary of the middle River Paraná in Argentina. The new genus is placed in the Monticelliinae because of the cortical position of the genital organs. It differs from all known monticelliine genera by the following combination of characters: (i) scolex robust, with a conical apex, without metascolex; (ii) biloculate suckers with a conspicuous septum separating unequally-sized loculi and a robust non-adherent area, lacking free posterior margin; (iii) vitelline follicles in two narrow lateral bands, extended throughout the nearly entire proglottid length; (iv) vagina always anterior to the cirrus-sac, with an inconspicuous vaginal sphincter; (v) a genital pore pre-equatorial. Scanning electron microscopy revealed three types of microtriches on the tegument surface: acicular and capiliform filitriches and gladiate spinitriches. A phylogenetic analysis of the large subunit nuclear ribosomal RNA gene (lsrDNA, D1-D3 domains) confirms that S. mabelae represents an independent lineage within a large clade comprised mainly from Neotropical taxa parasitising catfishes. This is the second proteocephalidean cestode described from a Neotropical synbranchiform fish host.
\end{abstract}

Keywords: Proteocephalidae, Monticelliinae, taxonomy, morphology, phylogenetic analysis, freshwater, Neotropical Region

In the Neotropical Region, the number of species of cestodes of the order Proteocephalidea Mola, 1928 (currently part of the Onchoproteocephalidea Caira, Jensen, Waeschenbach, Olson et Littlewood, 2014) is about one hundred but only 16 species of them occur in non-siluriform fishes of the orders Atheriniformes (1 sp.), Characiformes (7 spp.), Gymnotiformes (3 spp.), Perciformes (4 spp.) and Synbranchiformes (1 sp.) (Alves et al. 2017a).

During a survey of the helminth fauna of fishes from the River Paraná basin, specimens of a hitherto undescribed proteocephalidean species were collected from the intestine of the marbled swamp eel (Synbranchus marmoratus Bloch) (Synbranchiformes: Synbranchidae) and subjected to morphological and molecular analyses (lsrDNA, D1-D3 domains). These tapeworms were assigned to the Monticelliinae Mola, 1929, but could not be allocated to any of the known monticelliine genera. Therefore, a new genus is proposed to accommodate the new species described herein.

\section{MATERIALS AND METHODS}

Seventy-three specimens of Synbranchus marmoratus were caught by local fishermen in December 2009 and 2011 from the River Colastiné, Santa Fe Province, and in January, February and April 2010 and December 2011 from the River Paraná-Guazú, Entre Ríos Province, Argentina. Worms found in the intestine were removed, cleaned in saline, fixed in hot $4 \%$ formaldehyde solution and subsequently stored in $70 \%$ ethanol. Before this fixation for morphological observations, posteriormost proglottids of two specimens were excised and placed in molecular-grade 96-99\% ethanol for sequencing; hologenophore was preserved as a voucher (see Pleijel et al. 2008 for terminology).

Address for correspondence: N.J. Arredondo, Instituto de Biodiversidad y Biología Experimental y Aplicada (IBBEA, UBA-CONICET), Facultad de Ciencias Exactas y Naturales, Universidad de Buenos Aires, Ciudad Universitaria, Pabellón II, piso 4, Lab. 52, C1428EHA, Ciudad Autónoma de Buenos Aires, Argentina. Phone: +54 (11) 4576-330 ext. 332; Fax: +54(11) 4576-3384; E-mail: arredondonj@bg.fcen.uba.ar

Zoobank number for article: urn:lsid:zoobank.org:pub:F0C035BF-68EB-4235-81C0-21C2B31A88D0 
Entire tapeworms were stained with Langeron's alcoholic hydrochloric carmine (Langeron 1949), differentiated in acid ethanol, dehydrated through a graded ethanol series, cleared in beechwood creosote and mounted in Canada balsam. Details of the internal anatomy were determined from thick, hand-cut cross serial sections of proglottids stained with Langeron's alcoholic hydrochloric carmine. Spontaneously laid eggs were fixed in hot $4 \%$ formaldehyde solution and measured and illustrated in distilled water.

Pieces of two specimens of the new species were prepared for scanning electron microscopy (SEM) as follows: worms were postfixed in $1 \%$ osmium tetroxide, dried with hexamethyldisilazane (Riedel-De Haën ${ }^{\circledR}$, Hannover, Germany), mounted on stubs with adhesive tape, sputter coated with gold in a Thermo VG Scientific Polaron SC 7630 and examined with a Philips XL 30 scanning electron microscope. The types and distribution of microtriches were studied on the scolex, proliferation zone (neck) and immature proglottids. Measurements of the microtriches were taken from photomicrographs. Microthrix terminology follows Chervy (2009). Unless otherwise stated, all measurements are given in micrometres, with the range followed by mean and total number of measurements (n) in parentheses. For two-dimensional measurements, length is given before width. The relative size of the ovary was calculated according to de Chambrier et al. (2012). Illustrations were made with the aid of a camera lucida attached to a Zeiss Axioscope microscope equipped with differential interference contrast optics.

Total genomic DNA was extracted using a QIAamp DNA Blood kit (QIAGEN, Hilden, Germany) following manufacturer's instructions. The protocol for PCR amplification of the large subunit nuclear ribosomal RNA gene (lsrDNA, D1-D3 domains) and sequencing were done as described in Brabec et al. (2012). Contiguous sequences were assembled using Geneious version R8 (http://www.geneious.com/; Kearse et al. 2012) and submitted to GenBank. The newly generated sequence of $l s r$ DNA was aligned with related sequences retrieved from the GenBank database (see Table 1), using the E-INS-i algorithm of the program MAFFT (Katoh and Standley 2013) implemented in Geneious. The number of parsimony-informative characters was determined using PAUP* version 4a147 (Swofford 2002). The alignment was trimmed to match the shortest sequence and ambiguously aligned positions were manually excluded from subsequent analyses.

Phylogenetic reconstructions were performed with the Maximum likelihood (ML) and the Bayesian inference (BI) criteria, based on GTR $+\mathrm{I}+\Gamma$ model, predicted as best estimator by the small sample size corrected Akaike Information Criterion implemented in PartitionFinder v. 1.1.1 (Lanfear et al. 2012). The best ML estimate was obtained from 100 searches in the program GARLI ver. 2.01 (Zwickl 2006) using default settings and the nodal support was evaluated by running tree searches on each of the 100 bootstrap replicates in GARLI. A BI tree was constructed using MrBayes ver. 3.2 (Ronquist et al. 2012) running two independent MC3 runs of 4 chains (one cold, three heated) for 5 million generations (ngen $=5,000,000)$, sampling tree topologies every 1,000 th generation (samplefreq $=1,000$ ) and the first 500 samples were discarded as burn-in (burninfrac $=0.10$ ). Tracer v.1.6 (Rambaut et al. 2014) was used to check the convergence and mixing of different parameters and to confirm that the effective sample size (ESS) of each parameter was adequate to provide reasonable estimates of the variance in model parameters (i.e. ESS values $>200$ ).

Holotype was deposited in the Helminthological collection of the Institute of Parasitology of the Biology Centre, Czech Academy of Sciences, České Budějovice, Czech Republic (IPCAS) and paratypes at the Parasitological Collection of the Museo Argentino de Ciencias Naturales 'Bernardino Rivadavia', Buenos Aires, Argentina (MACN-Pa). For comparative purpose, the following monticelliine tapeworms that possess biloculate suckers were studied: type and voucher specimens of Chambriella megacephala (Woodland, 1934), Riggenbachiella amazonense Alves, de Chambrier, Luque et Scholz, 2017 and R. paranaense (Pavanelli et Rego, 1989) by one of the authors (PVA) (see Alves et al. $2017 \mathrm{~b}$ for the complete list of host and localities).

\section{RESULTS}

\section{Synbranchiella gen. $\mathrm{n}$.}

ZooBank number for genus: urn:1sid:zoobank.org:act:953C7E30-DCE7-4EC7-8313-6151134D0BDC

Diagnosis. Proteocephalidea, Proteocephalidae, Monticelliinae. Testes, ovary, vitelline follicles and uterus cortical. Medium-sized worms, flattened dorsoventrally. Strobila with acraspedote proglottids. Scolex subspherical to quadrangular, apex conical to slightly globose, without apical organ. Metascolex absent. Suckers biloculate, robust, with conspicuous septum separating loculi, lacking free posterior margin. Non-adherent area of suckers conspicuously developed. Internal longitudinal musculature formed by a few, small, sparsely distributed bundles of muscle fibres. Proliferation zone (neck) narrower than scolex. Testes cortical, arranged in one irregular field and one layer. Cirrus-sac thin-walled, elongated to pyriform. Genital pore pre-equatorial, irregularly alternating. Genital atrium present. Ovary cortical, butterfly-shaped, slightly lobulated. Vagina anterior to cirrus-sac, surrounded by small terminal vaginal sphincter near genital atrium. Vitelline follicles cortical, arranged in two narrow lateral bands. Uterine stem and uterine branches cortical. Uterine development of type 2 (sensu de Chambrier et al. 2004a). Parasites of Neotropical synbranchiform fish (Synbranchidae).

Type and only species: Synbranchiella mabelae sp. n. Ety mology: The new genus is named after the generic name of the host and should be treated as feminine.

Differential diagnosis. The new genus is placed in the Monticelliinae based on the position of the internal organs in relation to the inner longitudinal musculature (Schmidt 1986, Rego 1994, de Chambrier et al. 2009). The subfamily currently includes ten genera parasitising freshwater fishes in the Neotropics, Ageneiella de Chambrier et Vaucher, 1999; Chambriella Rego, Chubb et Pavanelli, 1999; Choanoscolex La Rue, 1911; Goezeella Fuhrmann, 1916; Manaosia Woodland, 1935; Monticellia La Rue, 1911; Regoella Arredondo, de Chambrier et Gil de Pertierra, 2013; Riggenbachiella Alves, de Chambrier, Luque et Scholz, 2017; Spasskyellina Freze, 1965 and Spatulif- 
Table 1. List of cestode specimens whose sequences of the large subunit nuclear ribosomal RNA gene (lsrDNA, D1-D3 domains) were included in the analyses. Genbank accession number in bold indicates the sequence generated as part of this study.

\begin{tabular}{|c|c|c|c|c|}
\hline Taxon & Host species & $\begin{array}{l}\text { Voucher Acc. } \\
\text { No. }{ }^{\dagger}\end{array}$ & $\begin{array}{l}\text { GenBank } \\
\text { Acc. No. }\end{array}$ & Reference \\
\hline $\begin{array}{l}\text { Ageneiella brevifilis } \\
\text { de Chambrier et Vaucher, } 1999\end{array}$ & Ageneiosus inermis (Linnaeus) & 21841 & AJ388600 & Zehnder and Mariaux 1999 \\
\hline $\begin{array}{l}\text { Amphoteromorphus ninoi } \\
\text { Carfora, de Chambrier et Vaucher, } 2003\end{array}$ & $\begin{array}{l}\text { Brachyplatystoma filamentosum } \\
\text { (Lichtenstein) }\end{array}$ & 22239 & AJ388624 & de Chambrier et al. 2004a \\
\hline Amphoteromorphus peniculus Diesing, 1850 & Brachyplatystoma rousseauxii (Castelnau) & 60052 & KP729410 & de Chambrier et al. 2015 \\
\hline Amphoteromorphus piraeeba Woodland, 1934 & Brachyplatystoma filamentosum & 22227 & KP729407 & de Chambrier et al. 2015 \\
\hline $\begin{array}{l}\text { Amphoteromorphus piriformis } \\
\text { Carfora, de Chambrier et Vaucher, } 2003\end{array}$ & Brachyplatystoma rousseauxii & 22211 & AJ275231 & de Chambrier et al. 2004a \\
\hline Brayela karuatayi (Woodland, 1934) & Platynematichthys notatus (Jardine) & 63128 & KP729406 & de Chambrier et al. 2015 \\
\hline Chambriella megacephala (Woodland, 1934) & Sorubimichthys planiceps (Spix et Agassiz) & $\begin{array}{l}91863-91865 \\
91867-91868 \\
69568,72973\end{array}$ & KY207449* & Alves et al. 2017b \\
\hline Choanoscolex abscisus (Riggenbach, 1895) & Pseudoplatystoma corruscans (Agassiz) & 17905 & AJ388630 & Zehnder and Mariaux 1999 \\
\hline Choanoscolex sp. & Pseudoplatystoma fasciatum (Linnaeus) & 25102 & AJ275064 & de Chambrier et al. 2004a \\
\hline Endorchis piraeeba Woodland, 1934 & Brachyplatystoma filamentosum & 21738 & AJ388603 & Zehnder and Mariaux 1999 \\
\hline Gibsoniela mandube (Woodland, 1935) & Ageneiosus sp. & 63119 & KP729412 & de Chambrier et al. 2015 \\
\hline $\begin{array}{l}\text { Gibsoniela meursaulti } \\
\text { de Chambrier et Vaucher, } 1999\end{array}$ & Ageneiosus inermis & 21839 & AJ388631 & Zehnder and Mariaux 1999 \\
\hline Goezeella siluri Fuhrmann, 1916 & Pinirampus pirinampu (Spix et Agassiz) & 21877 & AJ388612 & Zehnder and Mariaux 1999 \\
\hline Harriscolex kaparari (Woodland, 1 & $\begin{array}{l}\text { Pseudoplatystoma tigrinum } \\
\text { (Valenciennes) }\end{array}$ & 22018 & AJ275227 & Zehnder et al. 2000 \\
\hline Jauella glandicephalus Rego et Pavanelli, 1985 & Zungaru jahu (Ihering) & 31179 & KP729399 & de Chambrier et al. 2015 \\
\hline Megathylacus jandia Woodland, 1934 & Zungaro zungaro (Humboldt) & 21874 & AJ388596 & Zehnder and Mariaux 1999 \\
\hline Monticellia coryphicephala (Monticelli, 1891) & Salminus brasiliensis (Cuvier) & 17984 & AJ238832 & Zehnder and Mariaux 1999 \\
\hline $\begin{array}{l}\text { Monticellia ophisterni Scholz, de Chambrier et } \\
\text { Salgado-Maldonado, } 2001\end{array}$ & $\begin{array}{l}\text { Ophisternon aenigmaticum } \\
\text { Rosen et Greenwood }\end{array}$ & - & AY307121 & Scholz et al. 2003 \\
\hline Nomimoscolex admonticellia (Woodland, 1934) & Pinirampus pirinampu & 21870 & AJ388628 & Zehnder and Mariaux 1999 \\
\hline $\begin{array}{l}\text { Nomimoscolex chubbi (Pavanelli et Takemoto, } \\
\text { 1995) }\end{array}$ & Gymnotus carapo Linnaeus & 20351 & AJ388625 & Zehnder and Mariaux 1999 \\
\hline Nomimoscolex dorad (Woodland, 1935) & Brachyplatystoma rousseauxii & 22269 & AJ388613 & Zehnder and $\mathrm{M}$ \\
\hline Nomimoscolex lenha (Woodland, 1933) & Sorubimichthys planiceps & 21740 & AJ388611 & Zehnder and Mariaux 1999 \\
\hline Nomimoscolex lopesi Rego, 1989 & Pseudoplatystoma fasciatum & 21963 & AJ388618 & Zehnder and Mariaux 1999 \\
\hline $\begin{array}{l}\text { Nomimoscolex matogrossensis } \\
\text { Rego et Pavanelli, } 1990\end{array}$ & Hoplias malabaricus (Bloch) & 17913 & AJ388614 & Zehnder and Mariaux 1999 \\
\hline Nomimoscolex piraeeba Woodland, 1934 & $\begin{array}{l}\text { Brachyplatystoma capapretum } \\
\text { Lundberg et Akama }\end{array}$ & 22284 & AJ388608 & Zehnder and Mariaux 1999 \\
\hline Nomimoscolex sudobim Woodland, 1935 & Pseudoplatystoma fasciatum & 21969 & AJ388597 & Zehnder and Mariaux 1999 \\
\hline $\begin{array}{l}\text { Nomimoscolex suspectus Zehnder, de Chambri- } \\
\text { er, Vaucher et Mariaux, } 2000\end{array}$ & Brachyplatystoma vaillanti (Valenciennes) & 22298 & AJ388602 & de Chambrier et al. 2004a \\
\hline Nupelia portoriquensis Pavanelli et Rego, 1991 & Sorubim lima (Bloch et Schneider) & 35 & KP729401 & 2015 \\
\hline Ophiotaenia europaea Odening, 1963 & Natrix maura (Linnaeus) & 18407 & AJ388598 & Zehnder and Mariaux 1999 \\
\hline Ophiotaenia filaroides (La Rue, 1909) & Ambystoma tigrinum (Green) & 63372 & KP729416 & de Chambrier et al. 2015 \\
\hline Ophiotaenia paraguayensis (Rudin, 1917) & $\begin{array}{l}\text { Hydrodynastes gigas } \\
\text { (Duméril, Bibron et Duméril) }\end{array}$ & 16927 & AJ388629 & Zehnder and Mariaux 1999 \\
\hline Ophiotaenia cf. perspicua La Rue, 1911 & Nerodia rhombifer (Hallowell) & 5370 & KP729415 & de \\
\hline Ophiotaenia sanbernardinensis Rudin, 1917 & Helicops leopardinus (Schlegel) & 18251 & AJ388637 & Zehnder and Mariaux 1999 \\
\hline Ophiotaenia saphena Osler, 1931 & Lithobates pipiens (Schreber) & 32851 & KP729402 & de Chambrier et al. 2015 \\
\hline Peltidocotyle lenha (Woodland, 1933) & Zungaro zungaro & 22373 & AJ238837 & Zehnder and Mariaux 1999 \\
\hline Peltidocotyle rugosa Diesing, 1850 & $\begin{array}{l}\text { Pseudoplatystoma reticulatum } \\
\text { Eigenmann et Eigenmann }\end{array}$ & 22374 & AJ238835 & Zehnder and Mariaux 1999 \\
\hline Prote & Amia calva Linnaeus & 35548 & 6088 & 2009 \\
\hline Proteocephalus perplexus La Rue, 1911 & Amia calva & 35366 & FM956089 & de Chambrier et al. 2009 \\
\hline Proteocephalus sp. & Ictalurus punctatus (Rafinesque) & 36278 & FM956085 & de Chambrier et al. 2009 \\
\hline $\begin{array}{l}\text { Regoella brevis Arredondo, Gil de Pertierra et } \\
\text { de Chambrier, } 2013\end{array}$ & Pseudoplatystoma reticulatum & 79184 & KP729389 & de Chambrier et al. 2015 \\
\hline $\begin{array}{l}\text { Riggenbachiella amazonense Alves, } \\
\text { de Chambrier, Luque et Scholz, } 2017\end{array}$ & Sorubimichthys planiceps & $\begin{array}{l}\text { 60046, 60048, } \\
91866\end{array}$ & Y20 & al. 2 \\
\hline Spasskyellina lenha (Woodland, 1933) & Sorubimichthys planiceps & 69600 & KP729413 & de Chambrier et al. 2015 \\
\hline Spasskyellina spinulifera (Woodland, 1935) & Pseudoplatystoma corruscans & 34216 & KP729417 & de Chambrier et al. 2015 \\
\hline Spatulifer maringaensis Pavanelli et Rego, 1989 & Sorubim lima & 21986 & AJ388634 & de Chambrier et al. 2004a \\
\hline Synbranchiella mabelae gen. $\mathrm{n}$. et sp. $\mathrm{n}$. & Synbranchus marmoratus Bloch & $\begin{array}{l}\text { MACN-Pa } \\
619 / 2\end{array}$ & KY798870 & Present study \\
\hline Testudotaenia testudo (Magath, 1924) & Apalone spinifera (Le Sueur) & 35320 & FM956082 & de Chambrier et al. 2009 \\
\hline
\end{tabular}

$\dagger$ unless otherwise stated, all vouchers are deposited at the Natural History Museum, Geneva, Switzerland (acronym MHNG-PLAT); MACN-Pa - Parasitological Collection of the Museo Argentino de Ciencias Naturales 'Bernardino Rivadavia', Buenos Aires, Argentina; *seven identical replicates; **three identical replicates 
Table 2. Microthrix pattern of Synbranchiella mabelae gen. n. et sp. n. from Synbranchus marmoratus Bloch.

\begin{tabular}{|c|c|c|c|}
\hline Surfaces & $\begin{array}{l}\text { Microthrix } \\
\text { type }\end{array}$ & Size (length $\times$ width) & Fig. \\
\hline ASS & $\mathrm{CF}$ & $0.64-0.92(0.79) \times 0.10-0.16(0.12)(\mathrm{n}=9)$ & $\mathrm{E}$ \\
\hline MSS & $\mathrm{AF}-\mathrm{CF} / \mathrm{GS}$ & $\begin{array}{l}0.53-0.90(0.73) \times 0.08-0.15(0.11)(\mathrm{n}=9) \\
0.92-1.13(1.04) \times 0.47-0.64(0.56)(\mathrm{n}=8)\end{array}$ & $\mathrm{F}$ \\
\hline LSS & $\mathrm{CF} / \mathrm{GS}$ & $\begin{array}{l}0.78-1.06(0.92) \times 0.12-0.16(0.14)(\mathrm{n}=9) \\
1.00-1.37(1.19) \times 0.50-0.59(0.57)(\mathrm{n}=5)\end{array}$ & G \\
\hline SSS & $\mathrm{AF} / \mathrm{gs} / \mathrm{GS}$ & $\begin{array}{l}0.62-0.83(0.70) \times 0.12-0.16(0.14)(\mathrm{n}=6) \\
0.63-0.83(0.70) \times 0.33-0.42(0.39)(\mathrm{n}=5) \\
1.08-1.16(1.16) \times 0.51-0.57(0.55)(\mathrm{n}=5)\end{array}$ & $\mathrm{H}$ \\
\hline $\begin{array}{l}\text { N-ASS } \\
\text { (anterior- } \\
\text { medial) }\end{array}$ & $\mathrm{CF} / \mathrm{GS}$ & $\begin{array}{c}0.76-1.23(0.95) \times 0.10-0.17(0.13)(\mathrm{n}=15) \\
0.81-1.67(1.27) \times 0.40-0.69(0.58)(\mathrm{n}=9)\end{array}$ & I \\
\hline $\begin{array}{l}\text { N-ASS } \\
\text { (posterior) }\end{array}$ & $\mathrm{AF} / \mathrm{GS}$ & $\begin{array}{l}0.43-0.69(0.55) \times 0.11-0.13(0.12)(\mathrm{n}=5) \\
1.14-1.29(1.22) \times 0.60-0.66(0.63)(\mathrm{n}=4)\end{array}$ & $\mathrm{J}$ \\
\hline PZS & $\mathrm{AF}$ & $0.40-0.60(0.47) \times 0.11-0.14(0.12)(\mathrm{n}=6)$ & K \\
\hline IPS & $\mathrm{AF}$ & $0.32-0.36(0.33) \times 0.10-0.11(0.10)(\mathrm{n}=6)$ & $\mathrm{L}$ \\
\hline
\end{tabular}

Abbreviations: ASS - apical surface of the scolex; MSS - marginal surface of the suckers; LSS - luminal surface of the suckers; SSS - septum sucker surface; N-ASS - non-adherent surface of the suckers; PZS - proliferation zone surface; IPS - immature proglottid surface; AF - acicular filitriches; CF - capilliform filitriches; GS - gladiate spinitriches; gs - small gladiate spinitriches.

er Woodland, 1934. Synbranchiella gen. n. can be easily differentiated from Choanoscolex, Manaosia, Monticellia, Regoella, Spasskyellina and Spatulifer by its possession of biloculate, instead of uniloculate suckers. In Ageneiella, Chambriella, Goezeella and Riggenbachiella, the suckers are also biloculate, but the new genus can be distinguished from Ageneiella and Goezeella by the scolex morphology (quadrangular with a conical apex, without a metascolex $v \mathrm{~s}$ massive and with a collar-like metascolex, respectively), the development of the internal longitudinal musculature (weakly developed vs strongly developed in the two latter genera), and the arrangement of the vitelline follicles (two narrow lateral bands $v s$ two wide lateral bands [follicles only ventrally distributed in Goezeella], more concentrated posteriorly, with the ventral bands widened at ovary level) (see Fuhrmann 1916, de Chambrier and Vaucher 1999, de Chambrier et al. 2004b). In addition, the uterus of Synbranchiella is entirely cortical, whereas the uterine stem is cortical but some of the uterine diverticles penetrate the medulla in Ageneiella (see de Chambrier and Vaucher 1999).

Synbranchiella closely resembles Chambriella (syn. Lenhataenia de Chambrier et Scholz, 2008) and Riggenbachiella as recently characterised by Alves et al. (2017b). The new genus clearly differs from Chambriella and Riggenbachiella by the appearance of the scolex (subspherical to quadrangular in Synbranchiella vs quadrilobed, almost rectangular in apical view in the two latter genera), suckers (without free posterior margin overlapping the proliferation zone vs with free posterior margin in Chambriella and Riggenbachiella), in the presence of a conspicuous septum separating the two loculi of the suckers in Synbranchiella, combined with a robust and prominent non-adherent area of suckers ( $v s$ thinner and less conspicuous in Chambriella and Riggenbachiella), and the ovary in gravid proglottids (butterfly-shaped $v s$ bilobed and slightly follicular in the latter two). Additionally, Synbranchiella possesses a cir- rus-sac elongated to pyriform with a typical proteocephalidean sperm duct, whereas it is subovate with a thickwalled internal sperm duct in Chambriella and sigmoid, composed of three parts in Riggenbachiella (see de Chambrier and Scholz 2008, Alves et al. 2017b).

The study of the tegument surface of Synbranchiella mabelae gen. $\mathrm{n}$. et $\mathrm{sp}$. $\mathrm{n}$. revealed the presence of three types of microtriches that are typical for proteocephalidean cestodes, acicular and capiliform filitriches and gladiate spinitriches distributed on the scolex, proliferation zone and proglottid surfaces (see Table 2). The microthrix pattern observed in $S$. mabelae seems to be slightly different from those in species of Chambriella and Riggenbachiella. Only two microthrix types (acicular and gladiate spinitriches) were observed on the apex of the scolex, the non-adherent surface of suckers and anterior margins of suckers in these genera (see fig. 2 in Alves et al. 2017b), even though the complete microthrix pattern is not known in species of Chambriella and Riggenbachiella.

Synbranchiella mabelae gen. $\mathrm{n}$. et sp. n.

Figs. 1-4, Table 2

ZooBank number for species:

urn:lsid:zoobank.org:act:0AECC384-38EC-475F-B702-90F7D1F0F7CE

Description (based on two mature and one gravid specimens, transverse sections and two scolices studied using SEM from type locality). Proteocephalidae, Monticelliinae. Medium-sized worms, $28-88 \mathrm{~mm}(\mathrm{n}=3)$ in total length. Strobila acraspedote, flattened dorsoventrally, anapolytic, consisting of 37-67 (51; 3) immature proglottids (up to appearance of spermatozoa in vas deferens), 6-9 (8; 3 ) mature proglottids (up to appearance of eggs in uterus), 22 (1) gravid proglottids. Immature proglottids wider than long to longer than wide, 80-870 (465) $\times$ 400-690 (515; $17)$, length/width ratio $0.2-1.7: 1$. Mature proglottids longer than wide, 960-1,380 $(1,150) \times 400-870(660 ; 12)$, length/width ratio $1.3-2.4: 1$. Gravid proglottids longer than wide, $1.58-2.52 \mathrm{~mm}(2.07 \mathrm{~mm}) \times 500-960(750 ; 5)$, length/width ratio $1.7-5.0: 1$ (Figs. 1, 2B,C).

Scolex quadrangular, formed by four lobes separated by grooves in apical view, 710-800 (755) × 710-840 (775; 2), wider than proliferation zone, bearing 4 biloculate suckers. Apex conical, without apical organ, with numerous glandcells (Figs. 1, 2A, 4A,B,D). Suckers oriented anterolaterally, lacking free posterior margin, with loculi of unequal size, separating each other by a robust septum, anterior loculus 430-550 (490) × 230-320 (280), posterior loculus 300-340 (315; 7). Proliferation zone 460-560 (510) $\times$ 1.10-1.66 mm (1.33 mm; 2) (Figs. 1, 2A, 4A-D).

Apical surface of scolex (ASS) covered only with capiliform filitriches (Fig. 4E). Marginal surface of suckers (MSS) covered with acicular and capiliform filitriches interspersed with gladiate spinitriches (Fig. 4F). Luminal surface of suckers (LSS) covered with capilliform filitriches interspersed with gladiate spinitriches (Fig. 4G). Surface of septum of suckers covered with few acicular filitriches interspersed with gladiate spinitriches of two 

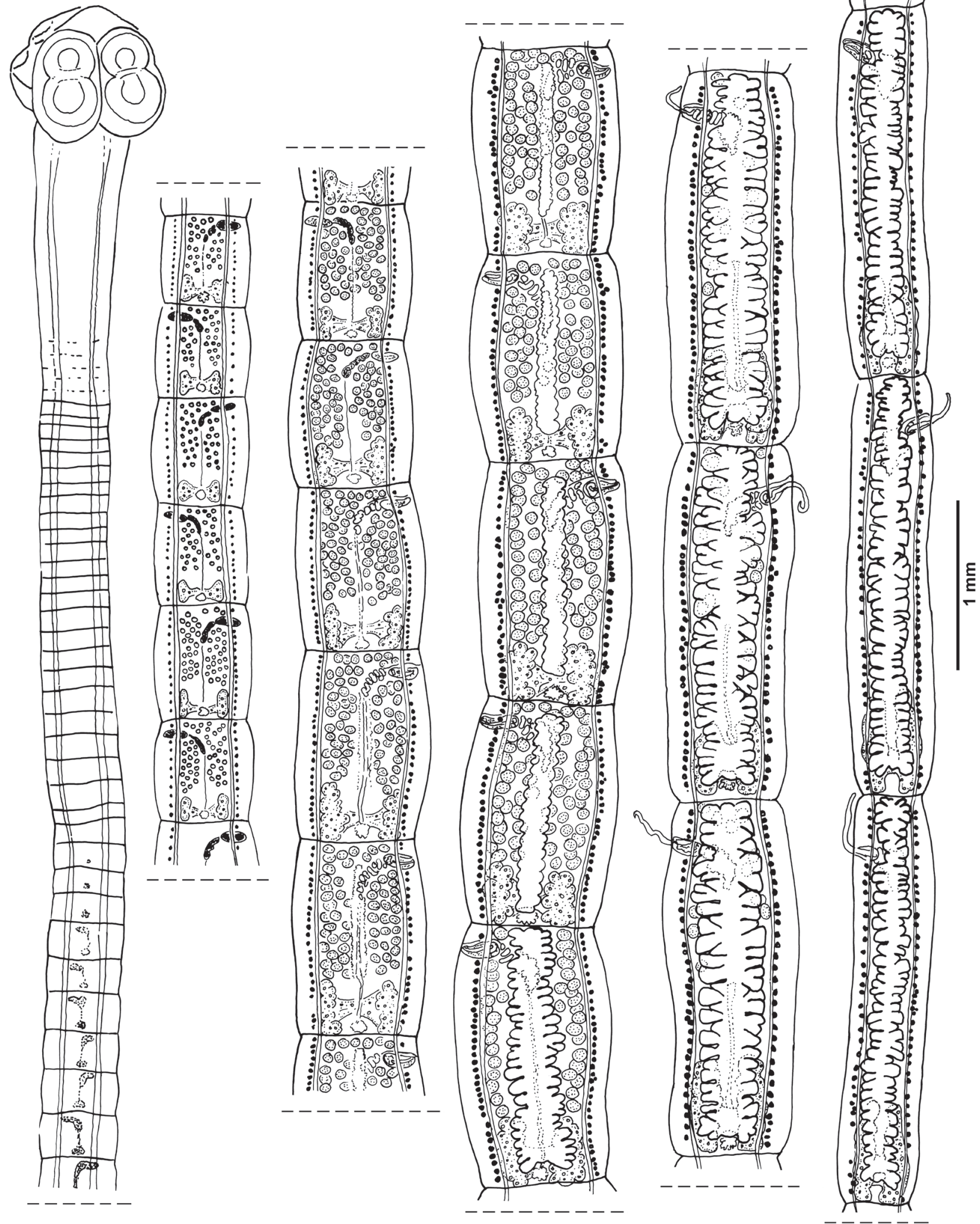

Fig. 1. Synbranchiella mabelae gen. n. et sp. n. from Synbranchus marmoratus Bloch (holotype IPCAS C-758). Entire worm, ventral view; dash lines indicate portions of strobila that are not shown.

sizes (Fig. 4H). Non-adherent surface of suckers (N-ASS) covered with capiliform filitriches interspersed with gladiate spinitriches on anterior and medial surfaces, filitriches diminishing in size from anterior to posterior surfaces (Fig. 4I,J). Proliferation zone surface and immature pro- glottid surface covered only with acicular filitriches (Fig. $4 \mathrm{~K}, \mathrm{~L})$. Tumuli observed in all surfaces, but more abundant on MSS, LSS and N-ASS (Fig. 4C,D) (see Table 2 for estimated size of microtriches). 

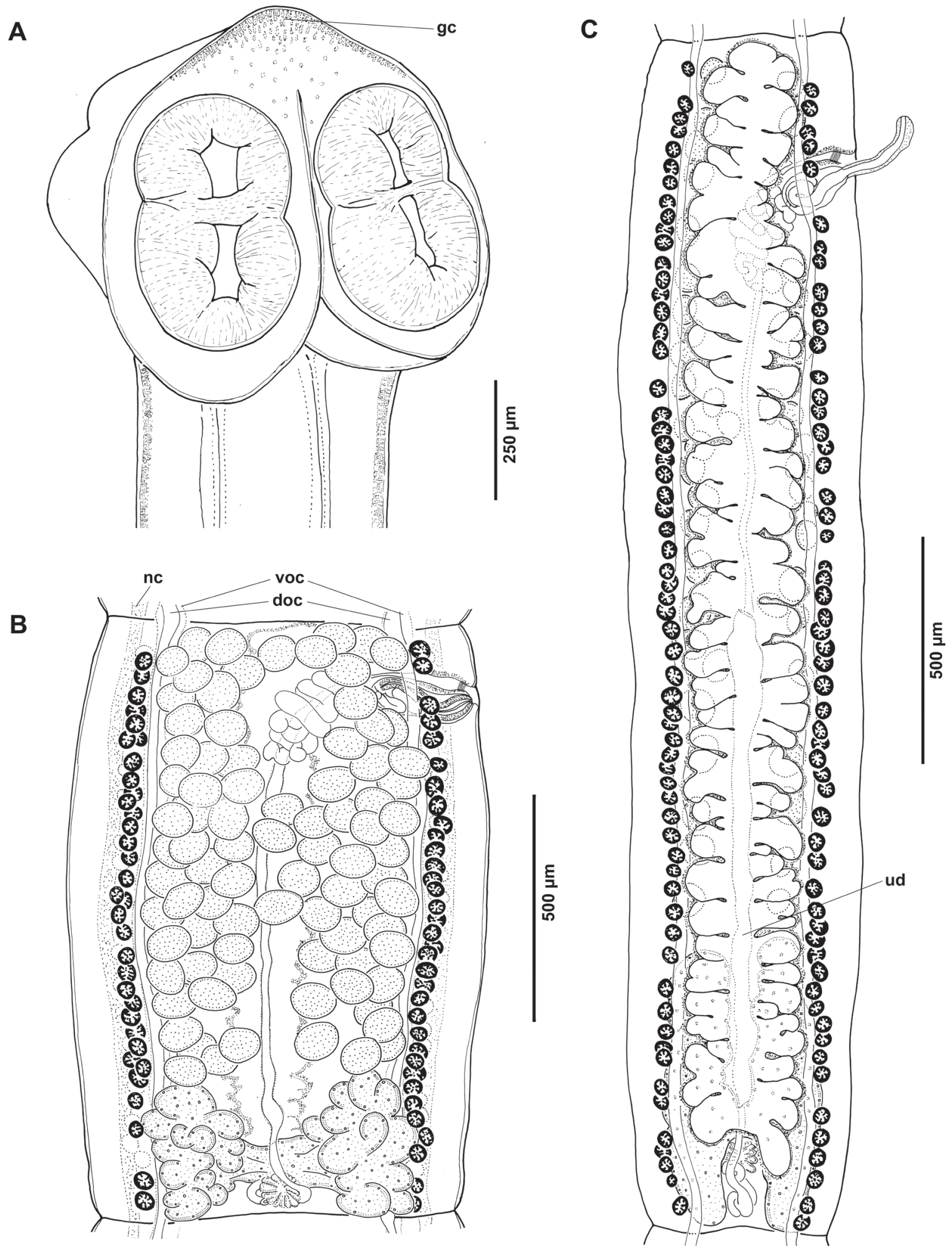

Fig. 2. Synbranchiella mabelae gen. n. et sp. n. from Synbranchus marmoratus Bloch (holotype, IPCAS C-758). A-scolex, dorsoventral view; B - mature proglottid, dorsal view; C - gravid proglottid, ventral view. Abbreviations: doc - dorsal osmoregulatory canal; gc - gland cells; nc - nerve corde; ud - uteroduct; voc - ventral osmoregulatory canal.

Internal longitudinal musculature weakly developed, represented by scarce bundles of isolated muscle fibres (Fig. 3D-F). Osmoregulatory canals situated between testes and vitelline follicles, often both canals overlapped by testes and ovary in dorsal view. Ventral canals 15-40 (30;
10) in diameter, dorsal canals $5-20(15 ; 10)$ (Figs. 2B,C, 3D-F).

Testes cortical, oval to spherical 45-100 (75) $\times 40-80$ $(65 ; 25) ; 77-101(88 ; 12)$ in total number per mature proglottid, arranged in one irregular field and one layer, usual- 

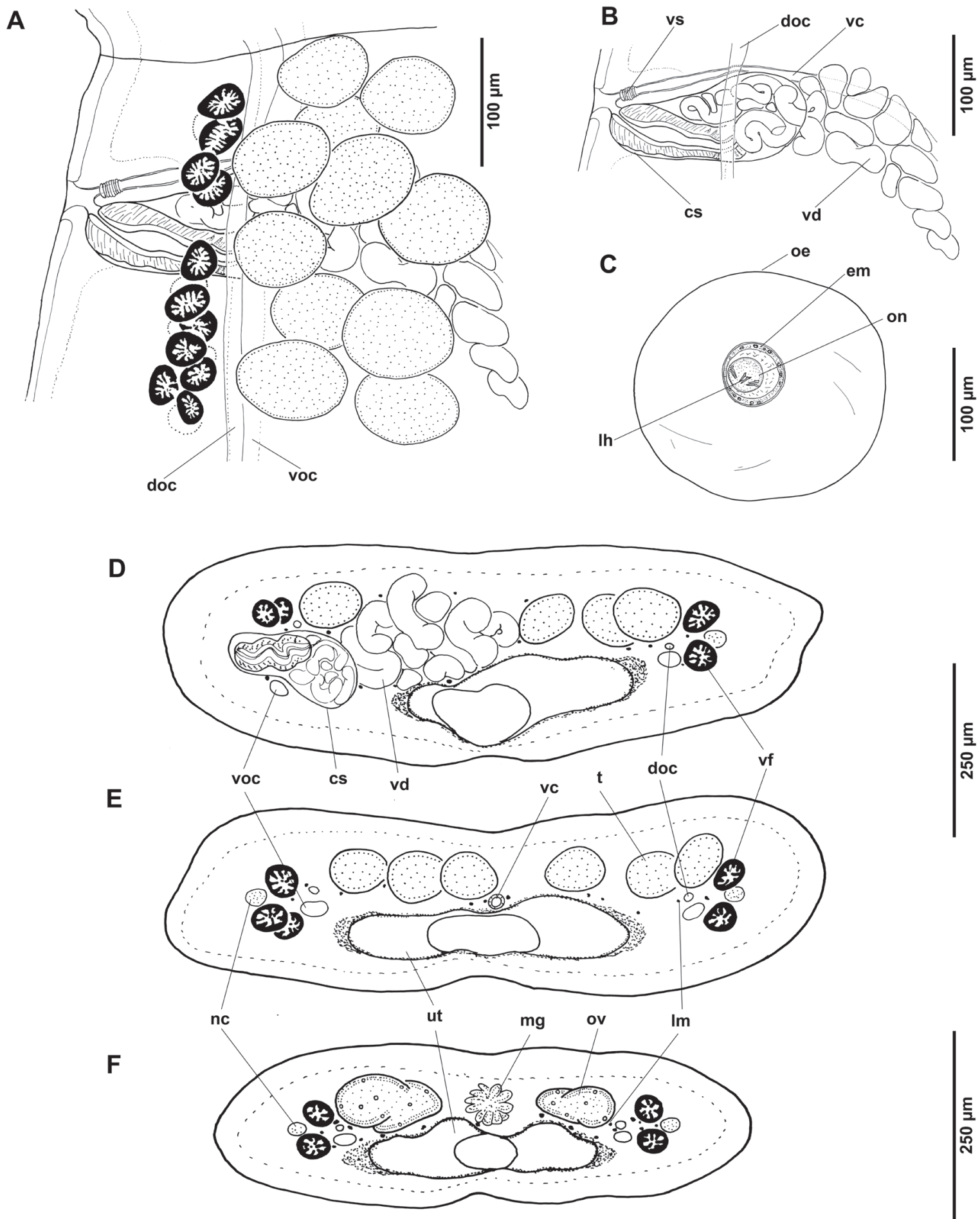

Fig. 3. Synbranchiella mabelae gen. n. et sp. n. from Synbranchus marmoratus Bloch (holotype, IPCAS C-758). A - detail of terminal genitalia, dorsal view; B - terminal genitalia (testes and vitelline follicles omitted), dorsal view; C - egg; D - cross-section at level of cirrus-sac; $\mathbf{E}$ - cross-section at level of testes; $\mathbf{F}$ - cross-section at level of ovary. Abbreviations: cs - cirrus-sac; doc - dorsal osmoregulatory canal; em - embryophore; $1 \mathrm{~h}$ - larval hooks; $1 \mathrm{~m}$ - longitudinal musculature; $\mathrm{mg}$ - Mehlis' gland; nc - nerve corde; oe - outer envelope; on - oncosphere; ov - ovary; $\mathrm{t}$ - testis; ut - uterus; vc - vaginal canal; vd - vas deferens; vf - vitelline follicles; voc - ventral osmoregulatory canal; vs - vaginal sphincter.

ly not surpassing osmoregulatory canals, overlapping cirrus-sac and ovary (Figs. 2B, 3A,D). Cirrus-sac elongate to pyriform, with thin muscular wall, 140-225 (200) × 65-90 (80; 12$)$, occupying $24-42 \%(31 \% ; n=12)$ of proglottid width in mature proglottids. Cirrus long, occupies $52-$ $79 \%(69 \% ; 12)$ of cirrus-sac length in mature proglottids
(Figs. 2B,C, 3A,B,D). Evaginated cirrus 325-415 (380) $\times$ $40-50(45 ; 5)$. Vas deferens coiled, $15-40(30 ; 21)$ in diameter, usually not surpassing mid-line in mature and gravid proglottids. Genital pores irregularly alternating, markedly pre-equatorial, $8-16 \%(12 \% ; 12)$ from anterior margin of proglottid in mature proglottids (Figs. 1, 2B,C, 3A). 

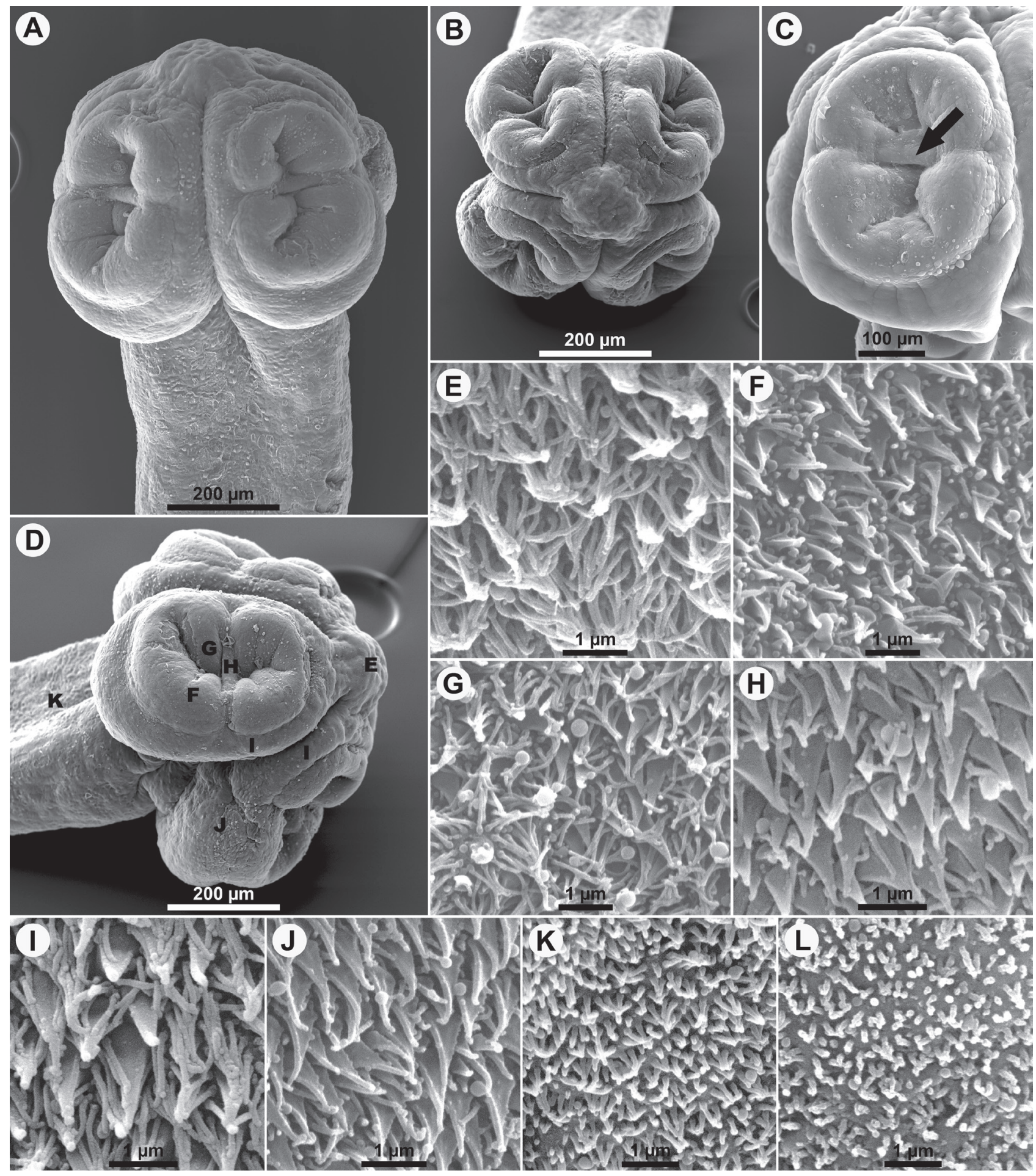

Fig. 4. Synbranchiella mabelae gen. n. et sp. n. from Synbranchus marmoratus Bloch, scanning electron micrographs. A-scolex, dorsoventral view; B - scolex, apical view; $\mathbf{C}$ - detail of sucker, arrow indicates septum; D - scolex, sublateral view; E-K letters indicate surfaces shown at high magnification in Fig. 4E-K; $\mathbf{E}$ - apical surface of scolex; $\mathbf{F}$ - marginal surface of suckers: $\mathbf{G}$ - luminal surface of suckers; $\mathbf{H}$ - surface of sucker septum; I - non-adherenth surface of suckers, anterior and medial zone; $\mathbf{J}$ - non-adherent surface of suckers, posterior zone; $\mathbf{K}$ - proliferation zone surface; $\mathbf{L}$ - surface of immature proglottid.

Ovary cortical, butterfly-shaped, slightly lobulate, $225-315(280) \times 235-590(400 ; 12)$, occupying $47-72 \%$ $(60 \% ; 12)$ of mature proglottid width (Figs. 1, 2B,C, 3F). Relative size of ovary surface to proglottid surface (sensu de Chambrier et al. 2012) 8-14\% $(11 \%$; $\mathrm{n}=11)$. Vagina thin-walled, always anterior to cirrus-sac, with small vaginal sphincter (difficult to observe), $10-15(13 ; 10)$ in diameter (Figs. 2B,C, 3A,B). Vitelline follicles cortical, arranged in 2 narrow lateral bands of 1-2 rows of follicles, occupy $97-100 \%$ of proglottid length. Some follicles overlapping ovary ventrally and vagina and cirrus-sac dorsally (Figs. 1, 2B,C, 3A, D-F). 


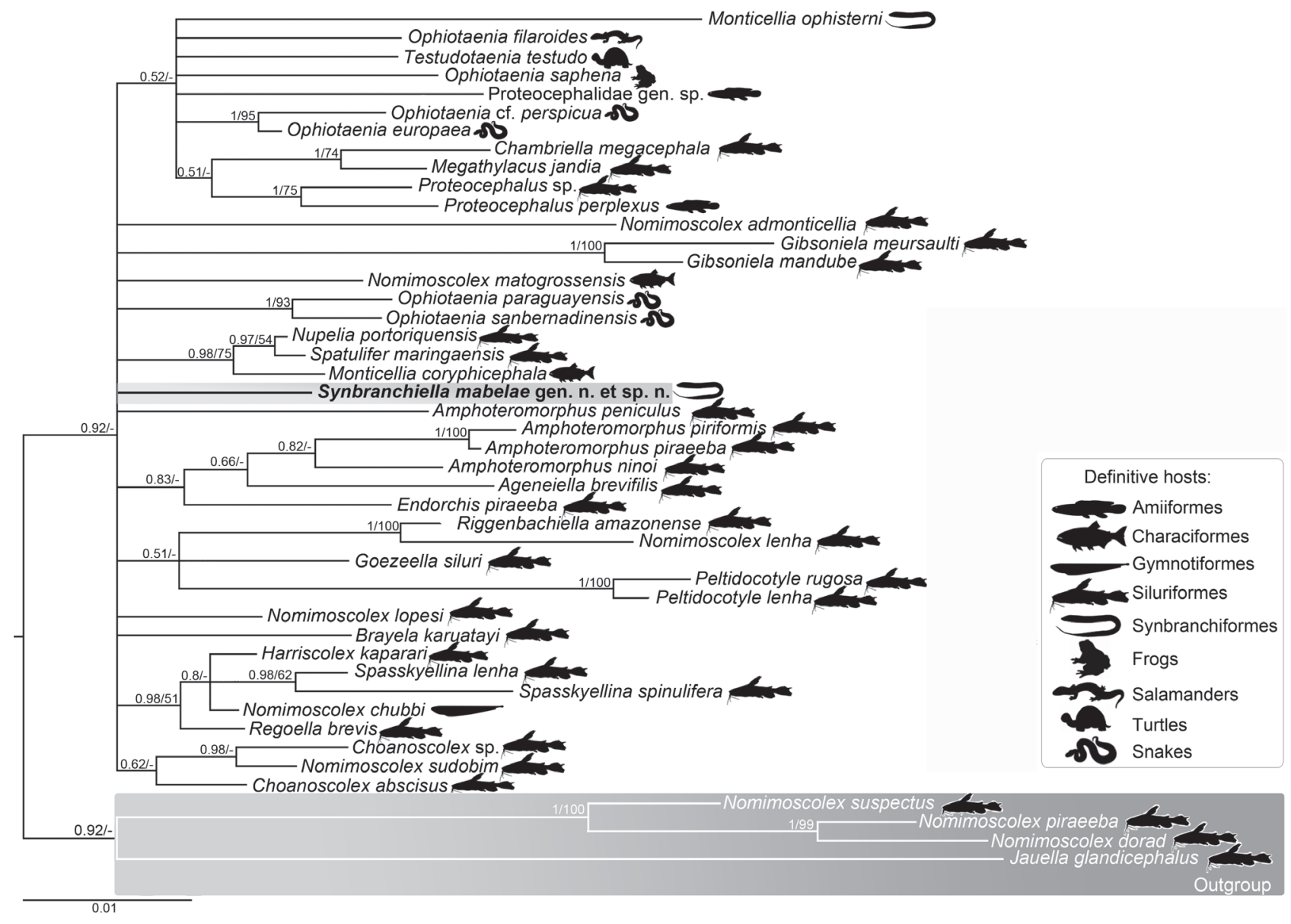

Fig. 5. Phylogram based on Bayesian Inference analysis of the partial $l s r$ DNA data. Nodal values indicate Bayesian posterior probabilities $>0.5$ and Maximum Likelihood bootstrap supports $>50$. Branch length scale bar indicates number of substitutions per site. Synbranchiella mabelae gen. n. et sp. n. from Synbranchus marmoratus Bloch in bold and demarcated in grey.

Uterine stem cortical, uterine development of type 2 (sensu de Chambrier et al. 2004a). Uterus entirely cortical, uterine branches situated in ventral cortex, occupying $43-58 \%(53 \% ; 5)$ of width of gravid proglottids. Aporal uterine branches $33-50(40 ; 5)$ in number, poral uterine branches $34-48(40 ; 5)$ in number. Uteroduct $760-1,000$ $(880) \times 45-55(50)$, occupying $35-41 \%(38 \% ; 3)$ of gravid proglottid length (Figs. 1, 2C, 3D-F).

First eggs released through several circular uterine apertures, later through longitudinal slit-like aperture extending ventrally along almost entire length of proglottid. Eggs spherical, with thin hyaline outer envelope 115-175 (140; 16) in diameter; embryophore $36-45(40 ; 16)$ in diameter; oncosphere $20-30(24 ; 16)$ in diameter, with embryonic hooks $8-13(10 ; 39)$ long (Fig. 3C).

Type and only known host: Synbranchus marmoratus Bloch (Synbranchiformes: Synbranchidae); vernacular name 'anguila criolla' in Argentina; marbled swamp eel in English.

Type locality: River Colastiné (tributary of the River Paraná; Middle Paraná), near Barrio Colastiné Sur, Santa Fe Province, Argentina (31 $\left.{ }^{\circ} 40^{\prime} \mathrm{S} ; 60^{\circ} 46^{\prime} \mathrm{W}\right)$.

O the r l o c a lity: River Paraná-Guazú (tributary of the River Paraná; Lower Paraná), Entre Rios Province, Argentina $\left(33^{\circ} 54^{\prime} \mathrm{S} ; 58^{\circ} 52^{\prime} \mathrm{W}\right)$.

Site of infection: Anterior intestine.
In fectio n rates: River Colastiné - prevalence, $17 \%(8 / 47)$, intensity 1-2 worms per host, mean intensity 1.3 , abundance 0.2; River Paraná-Guazú - prevalence 19\% (5/26), intensity 1-7 worms per host, mean intensity 2.4 , abundance 0.5 ; total number of worms 22; 19 immature, 2 mature, 1 gravid.

Type material: Holotype IPCAS No. C-758/1 (entire worm with serial transverse sections, on three slides), paratypes: MACN-Pa 619/1A,B (entire worm with serial transverse sections on two slides), MACN-Pa 619/2 (hologenophore; scolex used for SEM micrographs, strobila with serial transverse sections on one slide).

Molecular data: A fragment of 1,497 bp of the lsrDNA gene (D1-D3 domains) of one specimen of Synbranchiella mabelae was amplified. The nucleotide sequence is available in the GenBank database (Accession No. KY798870).

Etymology: The species is dedicated to the first author's mother Mabel Vera who also helped with collection of fishes.

Phylogenetic analysis. Partial lsrDNA (D1-D3 domains) sequence was generated de novo for a single representative of Synbranchiella mabelae gen. n. et sp. n. The trimmed $l s r \mathrm{DNA}$ alignment that also included representatives of clade D of de Chambrier et al. (2015), Monticellia ophisterni Scholz, de Chambrier et Salgado-Maldonado, 2001 (the only Neotropical proteocephalidean described from a synbranchid host), as well as representative se- 
quences of most morphologically similar species, i.e. C. megacephala and R. amazonense (see Table 1), was $976 \mathrm{bp}$ long and included 136 parsimony informative characters.

Bayesian inference and Maximum likelihood analyses produced phylograms with similar topologies (Fig. 5), even though weaker supported in the ML data (data not shown). The results showed a large polytomy with few well-supported internal nodes. Nevertheless, the molecular results revealed $S$. mabelae as an independent lineage, yet with uncertain phylogenetic position among the Neotropical proteocephalideans (Fig. 5). The morphologically similar taxa, C. megacephala and R. amazonense, clustered together with Megathylacus jandia Woodland, 1934 and Nomimoscolex lenha (Woodland, 1933), respectively, whereas M. ophisterni fell within a weakly supported clade composed, among others, from several species of Ophiotaenia La Rue, 1911 from amphibians and reptiles in the Palaearctic and Nearctic regions, also with unresolved position.

Pairwise comparison of the $l s r$ DNA sequences of $S$. mabelae with those of $R$. amazonense, C. megacephala and $M$. ophisterni revealed divergence levels of $2.6 \%$ (39 nt difference), 2.7\% (40 nt difference) and 4.8\% (48 nt difference), respectively.

\section{DISCUSSION}

Synbranchiella mabelae gen. n. et sp. n. belongs to the Monticeliinae based on the cortical position of the testes, ovary, vitelline follicles and uterus, as defined by Schmidt (1986), Rego (1994) and de Chambrier et al. (2009). The new species is allocated in a new genus because it possesses a unique combination of characters not present in any other monticelliine genera.

Recently, Caira et al. (2014) proposed the presence of gladiate spinitriches on the proliferation zone (or neck) of the Proteocephalidea and in the cephalic peduncle of the Onchobothriidae as a synapomorphy of the Onchoproteocephalidea. However, the type of microtriches that covers the proliferation zone has been scarcely included in the descriptions of proteocephalidean species and thus future studies should test validity of this putative synapomoprhy of the Onchoproteocephalidea. For example, the new species described herein, Spatulifer maringaensis Pavanelli et Rego, 1989 and Luciaella ivanovae Gil de Pertierra, 2009 have not gladiate spinitriches covering the proliferation zone (Arredondo and Gil de Pertierra 2008, Gil de Pertierra 2009, present study).

Phylogenetic analysis of the partial $l s r$ DNA sequence of Synbranchiella mabelae shows that this species does not cluster with any other Neotropical proteocephalidean, even though its relationship with the taxa remains unclear. It also indicates that the most morphologically similar taxa, i.e. C. megacephala and $R$. amazonense, are reciprocally monophyletic lineages, also with uncertain position within a large polytomy (see Fig. 5). It is argued that several events of colonisation of both hosts and zoogeographical regions, associated with rapid radiation in Neotropical teleosts, mainly pimelodid catfishes, largely contributed for the lack of genetic signal as estimated on the basis of the current ribosomal data (de Chambrier et al. 2004a, 2015). The results obtained in the present study support this assumption this assumption, as revealed by the low divergence levels of the $l s r$ DNA sequences, at least among representatives of three genera, i.e. Chambriella, Riggenbachiella and Synbranchiella; divergence levels ranged between $2.6 \%-4.8 \%$ (39-48 nt difference).

All three monticelliine genera possessing biloculate suckers are morphologically similar, but it is obvious from molecular analyses that this resemblance is a result of convergent evolution of morphological traits. Homoplasy of morphological characteristics, especially those of the scolex, has been observed in several groups of proteocephalideans [e.g. Scholz et al. 2013 - Macrobothriotaenia ficta (Meggitt, 1931)]. In South America, there are two other proteocephalidean genera from fishes that do not possess a metascolex and that bear four biloculate suckers in the scolex, similar to the members of the three above-mentioned monticelliine genera, i.e. Endorchis Woodland, 1934 (Endorchiinae) and Luciaella Gil de Pertierra, 2009 (Peltidocotylinae). Preliminary analyses of molecular data (partial sequences of $l s r$ DNA) support the assumption that biloculate suckers may have evolved independently in several lineages of proteocephalidean cestodes in the Neotropical Region (P.V.A. - unpubl. data).

Neotropical synbranchids are represented by two species of Ophisternon McClelland, namely O. aenigmaticum Rosen et Greenwood and O. infernale (Hubbs) distributed in Central America, and three species of Synbranchus Bloch, i.e. S. marmoratus, S. lampreia Favorito, Zanata et Assumpção and $S$. madeirae Rosen et Rumney, distributed in Central and South America (Froese and Pauly 2016). Only one proteocephalidean, Monticellia ophisterni, was previously found in synbranchids in the Neotropical Region (Scholz et al. 2001). Synbranchiella mabelae occurs in S. marmoratus, which has the most widespread distribution among the Neotropical synbranchids (Central and South America). Monticellia ophisterni differs from S. mabelae especially in the possession of uniloculate rather than biloculate suckers (see Scholz et al. 2001). Dissimilarity of these two monticelliine cestodes from swamp eels (synbranchiform fishes) well corresponds to their low level of relatedness as revealed by the phylogenetic analyses (Fig. 5) and distant distribution areas (northern Argentina vs southeastern Mexico). It is thus plausible to assume that synbranchiform fishes in the Neotropical Region were colonised by proteocephalidean cestodes independently. Curiously, $M$. ophisterni and $S$. mabelae have a relatively high prevalence of infection but most specimens were not fully mature or gravid (see Scholz et al. 2001 and infection rates in this paper). According to Scholz et al. (2001), the occurrence of $M$. ophisterni in an eel could be a result of host-switching, since other species of Monticellia have mainly been reported from siluriform or characiform fishes. Thus, the presence of proteocephalidean species in synbranchid fishes could either reflect a recent acquisition or an accidental host. Synbranchiella mabelae is the second proteocephalidean cestode described from a Neotropical 
synbranchiform fish host and the first one in South America.

Acknowledgements. Special thanks are due to Tomáš Scholz (České Budějovice, Czech Republic) for his fruitful comments during the preparation of this manuscript. This research was supported by the Universidad de Buenos Aires, Argentina (Grant
UBACyT 20020130100617BA) and Agencia Nacional de Promoción Científica y Tecnológica, Argentina (PICT No. 2358). P.V.A. was supported by a postgraduate fellowship from the Conselho Nacional de Desenvolvimento Científico e Tecnológico (CNPq), the Institute of Parasitology (RVO: 60077344) and the Czech Science Foundation (P505/12/G112).

\section{REFERENCES}

Alves P.V., de Chambrier A., Luque J.L., Scholz T. 2017b: Untangling convoluted taxonomy of Chambriella Rego, Chubb \& Pavanelli, 1999 (Cestoda: Proteocephalidae), with erection of Riggenbachiella $\mathrm{n}$. g. and description of a new species from pimelodid catfishes in the Neotropical Region. Syst. Parasitol. 94: 367-389.

Alves P.V., de Chambrier A., Scholz T., Luque J.L. 2017a: Annotated checklist of fish cestodes from South America. ZooKeys 650: 1-205.

Arredondo N.J., Gil de Pertierra A.A. 2008: The taxonomic status of Spatulifer cf. maringaensis Pavanelli \& Rego, 1989 (Eucestoda: Proteocephalidea) from Sorubim lima (Bloch \& Schneider) (Pisces: Siluriformes), and the use of the microthrix pattern in the discrimination of Spatulifer spp. Syst. Parasitol. 70: 223-236.

Brabec J., Scholz T., Králová-Hromadová I., BazsalovICSOvÁ E., OLSON P.D. 2012: Substitution saturation and nuclear paralogs of commonly employed phylogenetic markers in the Caryophyllidea, an unusual group of non-segmented tapeworms (Platyhelminthes). Int. J. Parasitol. 42: 259-267.

Caira J.N., Jensen K., Waeschenbach A., Olson P.D., LitTLEWOOD D.T. 2014: Orders out of chaos - molecular phylogenetics reveals the complexity of shark and stingray tapeworm relationships. Int. J. Parasitol. 44: 55-73.

de Chambrier A., Binh T.T., Scholz T. 2012: Ophiotaenia bungari n. sp. (Cestoda), a parasite of Bungarus fasciatus (Schneider) (Ophidia: Elapidae) from Vietnam, with comments on relative ovarian size as a new and potentially useful diagnostic character for proteocephalidean tapeworms. Syst. Parasitol. 81: 39-50.

de Chambrier A., Coquille S.C., Mariaux J., Tkach V. 2009: Redescription of Testudotaenia testudo (Magath, 1924) (Eucestoda: Proteocephalidea), a parasite of Apalone spinifera (Le Sueur) (Reptilia: Trionychidae) and Amia calva L. (Pisces: Amiidae) in North America and erection of the Testudotaeniinae n. subfam. Syst. Parasitol. 73: 49-64.

de Chambrier A., Rego A.A., Mariaux J. 2004b: Redescription of Brooksiella praeputialis and Goezeella siluri (Eucestoda: Proteocephalidea), parasites of Cetopsis coecutiens (Siluriformes) from the Amazon, and proposition of Goezeella danbrooksi sp. n. Rev. Suisse Zool. 111: 111-120.

de Chambrier A., Scholz T. 2008: Tapeworms (Cestoda: Proteocephalidea) of firewood catfish Sorubimichthys planiceps (Siluriformes: Pimelodidae) from the Amazon River. Folia Parasitol. 55: 17-28.

de Chambrier A., Vaucher C. 1999: Proteocephalidae et Monticelliidae (Eucestoda: Proteocephalidea) parasites de poissons d'eau douce au Paraguay, avec descriptions d'un genre et de dix espèces nouvelles. Rev. Suisse Zool. 106: 165-240.

de Chambrier A., Waeschenbach A., Fisseha M., Scholz T., MARIAUX J. 2015: A large 28S rDNA-based phylogeny confirms the limitations of established morphological characters for classification of proteocephalideans tapeworms (Platyhelminthes, Cestoda). ZooKeys 500: 25-59.

de Chambrier A., Zehnder M.P., Vaucher C., Mariaux J. 2004a: The evolution of the Proteocephalidea (Platyhelminthes, Eucestoda) based on an enlarged molecular phylogeny, with comments on their uterine development. Syst. Parasitol. 57: $159-171$.
Chervy L. 2009: Unified terminology for cestode microtriches: a proposal from the International Workshops on Cestode Systematics in 2002-2008. Folia Parasitol. 56: 199-230.

Froese R., Pauly D. (Eds.) 2016: FishBase. World Wide Web electronic publication. www.fishbase.org, 10/2016.

Fuhrmann O. 1916: Eigentümlische Fischcestoden. Zool. Anz. 46: 385-398.

Gil de Pertierra A.A. 2009: Luciaella ivanovae n. g., n. sp. (Eucestoda: Proteocephalidea: Peltidocotylinae), a parasite of Ageneiosus inermis (L.) (Siluriformes: Auchenipteridae) in Argentina. Syst. Parasitol. 73: 71-80.

Katoh K., Standley D.M. 2013: MAFFT multiple sequence alignment software version 7: improvements in performance and usability. Mol. Biol. Evol. 30: 772-780.

Kearse M., Moir R., Wilson A., Stones-Havas S., Cheung M., Sturrock S., Buxton S., Cooper A., Markowitz S., Duran C., Thierer T., Ashton B., Meintues P., DrumMOND A. 2012: Geneious Basic: an integrated and extendable desktop software platform for the organization and analysis of sequence data. Bioinformatics 28: 1647-1649.

Lanfear R., Calcott B., Ho S.Y.W., Guindon S. 2012: PartitionFinder: combined selection of partitioning schemes and substitution models for phylogenetic analyses. Mol. Biol. Evol. 29: 1695-1701.

Langeron M. 1949: Précis de Microscopie. Seventh Edition. Masson \& Cie, Paris, 1429 pp.

Pleijel F., Jondelius U., Norlinder E., Nygren A., Oxelman B., Schander C., Sundberg P., Thollesson M. 2008: Phylogenies without roots? A plea for the use of vouchers in molecular phylogenetic studies. Mol. Phylogenet. Evol. 48: 369-371.

Rambaut A., Suchard M.A., Xie D., Drummond A.J. 2014: Tracer v1.6. World Wide Web electronic publication, http://beast.bio.ed.ac.uk/Tracer, 11/2016.

Rego A.A. 1994: Order Proteocephalidea Mola, 1928. In: L.F. Khalil, A. Jones and R.A. Bray (Eds.), Keys to the Cestode Parasites of Vertebrates. CAB Intenational, Wallingford, pp. 257-293.

Ronquist F., Teslenko M., van der Mark P., Ayres D.L., Darling A., Höhna S., Larget B., Liu L., Suchard M.A., HuelsenbeCK J.P. 2012: MrBayes 3.2: efficient Bayesian phylogenetic inference and model choice across a large model space. Syst. Biol. 61: 539-542.

SchmidT G.D. 1986: CRC Handbook of Tapeworm Identification. CRC Press, Inc., Boca Raton, Florida, 675 pp.

Scholz T., De Chambrier A., Kuchta R., Littlewood D.T.J., Waeschenbach A. 2013: Macrobothriotaenia ficta (Cestoda: Proteocephalidea), a parasite of sunbeam snake (Xenopeltis unicolor): example of convergent evolution. Zootaxa 3640: 485-499.

Scholz T., de Chambrier A., Salgado-Maldonado G. 2001: Monticellia ophisterni n. sp. (Cestoda: Monticellidae) from the swamp-eel Ophisternon aenigmaticum (Synbranchiformes) from Mexico. J. Parasitol. 87: 1328-1333.

Scholz T., Rosas-Valdez R., Pérez-Ponce de León G., Choudhury A., De Chambrier A. 2003: Taxonomic status of Choanoscolex lamothei García-Prieto, 1990 (Cestoda: Proteocephalidea) using morphological and molecular evidence. J. Parasitol. 89: 1212-1219. 
Swofford D.L. 2002: PAUP*. Phylogenetic Analysis Using Parsimony (*and Other Methods), version 4.0. Sinauer Assoc., Sunderland, Massachusetts.

Zehnder M.P., de Chambrier A., Vaucher C., Mariaux J. 2000: Nomimoscolex suspectus n. sp. (Eucestoda: Proteocephalidea, Zygobothriinae) with morphological and molecular phylogenetic analyses of the genus. Syst. Parasitol. 47: 157-172.
ZeHnder M.P., Mariaux J. 1999: Molecular systematic analysis of the order Proteocephalidea (Eucestoda) based on mitochondrial and nuclear rDNA sequences. Int. J. Parasitol. 29: 1841-1852.

ZWICKL D.J. 2006: Genetic algorithm approaches for the phylogenetic analysis of large biological sequence datasets under the maximum likelihood criterion. PhD thesis, University of Texas at Austin, $115 \mathrm{pp}$.

Cite this article as: Arredondo N.J., Alves P.V., Gil de Pertierra A.A. 2017: A new genus of proteocephalid tapeworm (Cestoda) from the marbled swamp eel Synbranchus marmoratus Bloch (Synbranchiformes: Synbranchidae) in the River Paraná basin, Argentina. Folia Parasitol. 64: 015. 